\title{
INVESTIGATING THE READING COMPREHENSION ABILITY OF GRADE 9 (FORM 2) LEARNERS AT BULAWAYO CENTRAL DISTRICT HIGH SCHOOLS IN ZIMBABWE
}

T. Gumede Hillside Teachers' College, Zimbabwe

N.A.Y. Boakye University of Pretoria, South Africa

\begin{abstract}
Reading ability is important in education, as it transcends all forms of learning. Poor reading ability usually means that a learner will encounter academic challenges and perform poorly at school. Grade 9 (form 2) learners in Zimbabwe were thought to have been disadvantaged during Zimbabwe's economic turmoil from 2006 to 2008. There were so many disruptions and instances of absenteeism in government schools during that period that these learners, who were in grade $R$ at the time, may not have received adequate reading instruction. The aim of the study was to investigate the reading comprehension levels of grade 9 (form 2) learners in Bulawayo Central District high schools in Zimbabwe to determine whether they were disadvantaged by the disruptions, and to what extent. Quantitative and qualitative methods were used to collect data to establish the learners' reading proficiency and to determine what factors influenced their reading proficiency. Forty-eight learners from government schools and 22 from private schools voluntarily wrote a reading comprehension test and provided narratives on their reading development. The test results were analysed using ANOVA and the narratives were analysed using content analysis. The test results showed that the reading comprehension level of the cohort of grade 9 (form 2) learners in government schools was below that expected for grade 4. The narratives of the government school learners were also fraught with errors, whereas private school learners wrote better narratives. The study therefore showed that the reading proficiency of the government school learners who were in grade $R$ in 2008 was below the required level. The learners' reading development seems to have been adversely affected by the national disruptions. Recommendations are made for interventions to improve the reading proficiency of grade 9 learners in government schools before they pursue tertiary education.
\end{abstract}

Keywords: Reading comprehension, reading proficiency, Private school, Government school, Economic turmoil in Zimbabwe, Grade 9 (form 2)

\section{INTRODUCTION}

Reading is an interactive skill involving a reader and the text (Grabe \& Stoller, 2011: 27). It forms the basis of all areas of learning and is a fundamental skill that needs to be acquired by every learner at school. According to Bohlman and Pretorius (2002: 205), learners who fail to master this essential learning tool risk facing challenges in the academic environment. For many African learners, reading proficiency has to be developed in English from grade 4 as English is the language of learning and teaching (LoLT). In Zimbabwe, English is an official language and an additional language for the majority of learners. Learners have to be proficient readers in English, not only for the purpose of language and literature study, but 
also for learning other subjects in the school curriculum (Geske \& Ozola, 2008: 71). Learners who are competent at reading in the LoLT are able to learn on their own, both inside and outside the classroom, and are academically successful (Ntereke \& Ramoroka, 2017).

However, reading comprehension does not develop naturally; learners need well-planned and deliberate patterns of reading to achieve comprehension, especially in the language of instruction. Learners who do not receive close monitoring, adequate pacing, clarity of presentation and well-structured reading lessons in the LoLT may fail to learn to read in the early grades and become handicapped readers in later grades (OECD, 2009). For example, according to Mason (in Erlinda \& Roinasol, 2016: 2), children need to learn explicitly the phonic knowledge (letter-to-sound correspondences) in order to decode and spell unfamiliar words. Simmons, Kame'enui, Harn, Michael and Stoolmiller (2007) point out that there is a window of opportunity to teach young children these decoding skills, using well-focused and intensive instruction.

A number of learners in Zimbabwe may have skipped this crucial reading tutorial during the country's economic turmoil from 2006 to 2008, when the education sector experienced massive disruptions. Kanyenze, Kondo, Chitambara and Martens (2011) posit that there was subdued teaching and regressed learning between 2006 and 2008, resulting in low pass rates at both primary and secondary levels. The effect may have been more pronounced in government schools as $92 \%$ of school heads interviewed confirmed that there was no meaningful teaching and learning in 2008 (UNICEF-SNV, 2009: 388). Thus, learners who were in grades $\mathrm{R}$ and 1 at the time may have missed an important reading development stage of their education.

The Zimbabwe Ministry of Education attempted to redress the perceived reading performance lag through interventions such as the Early Reading Initiative (ERI) (Ministry of Secondary and Primary Education [MOPSE], 2012a) and the Performance Lag Address Programme (PLAP) (MOPSE, 2012b). The aim of the ERI was mainly to address the challenges primary school teachers experience in the teaching of pre-reading skills in Early Childhood Development (equivalent to grade 0 or grade R). The PLAP, on the other hand, was aimed at secondary school learners to address the reading achievement gaps mainly caused by the regressed learning and subdued teaching from 2006 to 2008 (Nkoma, 2014). Secondary school learners were assessed and given interventions appropriate to their competence level (Muzawazi \& Nkoma, 2011). However, after being piloted briefly, the programme was discontinued due to lack of funding and other logistical problems (Dube, 2015; MOPSE, 2012b; Mukoko \& Mdlongwa, 2014; Nkoma, 2014). Thus, the ERI and PLAP were halted abruptly, and no further redress programmes have been undertaken, either to assist the learners or to investigate their reading proficiency levels. Learners were therefore left to struggle in mainstream teaching without any interventions (Nkoma, 2011).

Considering the limited teaching and learning that took place from 2006 to 2008, it is crucial that the reading proficiency of learners who were in grades $\mathrm{R}$ and 1 be investigated and strong advocacy be made for appropriate interventions to be put in place should their reading levels be found to be far below the required level. Thus, the study was conducted to investigate the reading proficiency of a cohort of grade 9 (form 2) learners who were in grades $\mathrm{R}$ and 1 at the time of Zimbabwe's economic crisis. This group of learners was selected for the study because of the challenges related to the crisis, and because there has been no known specific study of this group of learners in Zimbabwe. Most research has focused on reading at elementary level up to grade 4 (Robert, 2013). There is therefore a 
paucity of research on reading interventions for older learners, such as those in grade 9 (form 2), who may be experiencing reading difficulties.

\section{Teaching in Zimbabwean schools during the economic crisis}

In a study conducted by Moyana (2000), Zimbabwe was considered to be a country with very large school populations and large class numbers. In 2009, studies revealed that $20 \%$ of urban primary schools had a textbook ratio of 9:1 nationally, while eight percent of schools had no textbooks at all (Millennium Development GOALS Zimbabwe report, 2010). Under these circumstances, learners' English repertoire and learning motivation are thin and low (Kung, 2019: 96). Enkin (2014: 52) contends that reading materials should be of high interest and relate well to the background of the reader since strong semantic input can help when syntactic control is weak.

Younger learners are to be guided by teachers to arrive at appropriate background knowledge (Enkin, 2014: 31). Without the appropriate background knowledge, learners may experience what Byram (2000) and Sharma (2007) term culture shock, which they describe as psychological and social disorientation. Teachers trained at most colleges in Zimbabwe have limited knowledge and skills of teaching learners with reading challenges unless they have had special training for handling learners with special needs. Most of the time, teaching reading comprehension is undertaken through inappropriate methods, which is compounded by the rush to complete syllabi and for students to take their final examinations (Moyana, 2000: 184).

During the economic crisis in Zimbabwe, there was a shortage of teachers as many left for other countries (Coltart, 2008: 7). The few teachers who remained traded in various goods to make ends meet and did not attend classes regularly (Besada \& Moyo, 2008: 10). When they did attend class and attempted to teach, they did so in very superficial ways without attention to improving learners' competency, but rather merely concentrating on completing the syllabus (Muchemwa, 2014: 198). There was a general lack of motivation on the teachers' part. The learners also lacked motivation to learn as there was no parental guidance (Gumede, 2018: 94). A number of learners often stayed away from school (Kanyenze, Kondo, Chitambara \& Martens, 2011: 67). In effect, learning in government schools was almost halted. Private schools, however, had more stability as teachers were paid in foreign currency and did not need to look for extra income elsewhere (Gumede, 2018: 100).

Learners in this study may have lacked the teachers' orientation and guidance, which Tamrackitkun (2010: 36) contends is crucial in guiding readers to gain vocabulary, knowledge and fluency. A majority of learners may therefore be encountering challenges in reading in English at the secondary school level, as shown by the assessments in the PLAP (Mutepfa, Mpofu \& Chataika, 2007). The aim of this study was therefore to determine the reading proficiency of learners in Bulawayo Central District in order to suggest appropriate redress strategies for their reading challenges.

The main research question set for the study was:

What is the reading proficiency level of grade 9 (form 2) learners in Bulawayo Central District high schools in Zimbabwe? 
The sub-questions were:

(1) What is the reading comprehension level of grade 9 (form 2) learners in government and private schools in Bulawayo Central District in Zimbabwe?

(2) To what extent and how did the cohort of learners develop their reading proficiency in the lower grades?

\section{LITERATURE REVIEW}

Tamrackitkun (2010: 14) premises that 'the earliest definition of reading can be traced back to Huey (1908), whose focus was on the process used to gain information from printed material and the means by which the mind takes note of these printed words.' A similar definition is proffered by Walcutt (1967: 363), where reading is argued to be the ability to decode symbols and comprehend printed material. These definitions advocate for phonics and perceive reading as awareness of sounds and grouping of sounds (Denton \& Otaiba, 2011). Although phonological awareness - in particular phonemic awareness - is an important aspect of reading, on its own it does not enable the reader to achieve comprehension or proficiency. This awareness only enables a reader to decode the information.

Many reading researchers have argued that reading cannot occur by decoding alone, without obtaining comprehension. According to Gough and Tunmer's (1986) simple view of reading (SVR), reading is viewed as a product of decoding and comprehension, and this requires proficiency in both decoding and comprehension. If either decoding or comprehension is lacking, the reader is said to be unable to comprehend the text (Kang, 2015: 19). Lack of comprehension skills results in hyperlexia, and if readers have poor decoding and comprehension skills, it results in what Gough and Tunmer (1986) term 'garden variety disability' (Kang, 2015: 19). Early researchers such as Anderson and Pearson (1984) concur with the assertion that reading cannot occur without comprehension.

Contemporary researchers such as Grabe and Stoller (2013) and Panigrahi (2010) view reading as a skill that involves the construction of meaning from texts. In view of this, Grabe and Stoller (2011: 3) define reading as 'the ability to draw meaning from the printed page and interpret this information appropriately.'

However, these simple definitions do not bring to light the variety of ways in which readers engage with texts in order to read accurately, such as the ability to make inferences, activation of background knowledge, prediction of what is read, generating visual images, summarising, self-questioning, analysing grammar elements, distinguishing important detail, synthesising what is read, monitoring what is read and learning how to repair meaning, among other elements suggested by Harding, Alderson and Brunfaut (2015).

According to Harding et al. (2015), these elements are crucial in reading development and should form part of the reading instruction that teachers ought to impart to learners if reading comprehension is to be achieved. Grabe and Stoller (2011), together with other reading researchers such as Jiang (2017), Dhanapala and Yamada (2015), Allen, Snow, Crossley, Jackson and McNamara (2014), Landi (2010), Nassaji (2003) and Anderson (2000), affirm that reading comprehension operates at two levels, namely, the lower level and higher level.

The lower level involves word recognition, where readers link written symbols to sound symbols. Readers also work out meanings at word and sentence level using working memory. 
At the higher level, reading involves topic and world knowledge, making inferences and building mental models on what is read. Readers also monitor what they read by checking whether it has been understood, and finally synthesise and evaluate what they read (Boakye, 2017; Grabe \& Stoller, 2011; Harding et al., 2015). Hence, reading comprehension is viewed as a transaction between the reader and the text, in which the reader brings to the text world knowledge to confirm what is being read (Grabe \& Stoller, 2011).

Young learners might not achieve the reading transaction referred to by Grabe and Stoller (2011), and may not be able to adequately develop the lower- and higher-order reading abilities without the assistance of a teacher or a guide, as proposed by Gove and Cvelich (2011). Gove and Cvelich (2011) maintain that reading skills do not develop naturally, and the teacher ought to be a stakeholder in the reading process to provide a stimulating learning environment. Similarly, Vesay and Gischlar (2013: 294) state that 'the greatest impact on teaching children to read is the quality and skill of the teacher who is implementing the curriculum.' Learners who are guided through pre-reading, reading and post-reading are said to gain interest in reading. On the contrary, those who are taught reading comprehension by 'discussing the text, answering the questions about the text and assessing [them] to determine whether they understood the text' (Ness, 2009: 74) lose interest in reading to some degree, as this represents a narrow approach to reading comprehension (Ness, 2009: 74).

Besides the explanation of reading provided earlier, social and affective factors also influence learners' reading development (Boakye, 2017; Grabe \& Stoller, 2011; Guthrie, 2008). Grant, Golden and Wilson's (2015) definition regards engagement with reading material and motivation to read as important and crucial in reading development. In addition, socioeconomic status (SES) is said to be strongly associated with many measures of childhood cognitive and academic achievement, including intelligence quotient and ability to comprehend (Dexter, 2013). Children from lower SES homes are envisaged as having less reading practice before they begin their schooling (Hindman \& Morrison, 2012), which disadvantages them in school. A similar view is held by Hoff (2013: 10), who postulates that children from lower SES homes frequently have lower levels of language skills than the schools require because they engage in less speaking and reading with their parents and others around them. Hoff (2013: 11) suggests that schools should welcome and respect all children, and that extra support should begin early and be sustained for as long as the children's skill levels are at risk.

Research also indicates that younger learners have more positive reading attitudes as they are considered more enthusiastic about beginning their reading journey than older readers (Knell, 2012). Findings in the study by Knell (2012: 5) also indicate that learners become disinterested when frequently confronted with challenging reading tasks as they progress. Hence, learners are to be equipped with reading skills at a tender age so that they approach reading with a positive attitude as they develop (Lukhele, 2013: 1). In their research, Edmonds et al. (2009) found that young beginner readers benefit from modelling and thinking aloud, and that these readers model their teachers, either by asking themselves questions in order to reflect on what is being read or by reading aloud what their teacher has read. Moreover, Richardson (2010) strongly believes that learners should be taught reading comprehension using the three-phase approach, where they are guided in pre-reading, reading and post-reading strategies that would also promote sessions of interrogation of background knowledge, vocabulary and comprehension skills. Taylor and $\mathrm{Yu}$ (2009) argue that appropriate reading instruction at a younger age benefits the learners in the higher grades. However, poor reading development at the lower levels disadvantages learners immensely in Per Linguam 2020 36(1):71-89 http://dx.doi.org/10.5785/36-1-938 
the higher grades, and in life generally. The same sentiments are echoed by Muchemwa (2014: 194), who strongly contends that inability to read can lead to 'humiliation, impediment to further studies, limited wisdom and missing the joys of learning from the printed page.' Also of concern is the way teachers handle teaching comprehension. According to Ntereke and Ramoroka (2017: 3), teachers of literacy were discovered to lack the requisite training to teach higher-level skills on reading comprehension. Thus, reading comprehension as a cognitive construct is directly related to several other variables, such as the reader's prior knowledge, interest, motivation, SES, strategies employed by the teacher, and most importantly, instruction at a younger age.

In light of the discussion on reading and the adequate development thereof, it is evident that learners from government schools who were in grades R and 1 during 2008/2009 may have been adversely affected by the economic turmoil. These learners may have been denied early reading tutorials or had inadequate and ineffective instruction that was not at the required level, as classes were often disrupted and absenteeism by both learners and teachers was rampant at government schools (Kanyenze et al. 2011). Thus, the study sought to investigate these learners' reading comprehension levels and what factors may have influenced their reading development.

\section{METHODOLOGY}

A qualitative-quantitative research approach was used for this study. According to Okeke and Van Wyk (2015: 180), a mixed methods approach focuses on 'the data that are both numerical and textual in nature.' Quantitative data for this study were collected using the Progress International Reading Literacy Study (PIRLS) comprehension test (Mullis, Martin, Foy \& Drucker, 2011). The qualitative approach was employed through content analysis, which was carried out on learners' written narratives of their literacy development from childhood to grade 9 (form 2 ).

\section{Population and participants}

Four schools (two private and two government) were selected from the Bulawayo Central District due to their proximity to the principal researcher. It was necessary to obtain data from both private and government school learners, as the economic crisis mostly affected government schools. Private schools were more stable and barely affected. Thus, a comparison of the learners from the two schools was necessary to determine the effect of the crisis on learners. A total of 70 learners participated in the study: 48 from government schools and 22 from private schools. There were 29 male and 41 female learners from all four schools. There were 29 female and 19 male learners from government schools, and 12 female and 10 male learners from private schools. The detailed demographic information is given in Table 1 below.

Participants were voluntarily drawn from the school types as shown in the demographic table. There were roughly the same numbers of female learners as male learners attending both school types, yet more female than male learners volunteered. Gender was not an aspect of this study; hence, it will not be discussed further. 
Table 1: School and gender distribution of learners

\begin{tabular}{|l|l|l|l|}
\hline Variable & Category & N & \% \\
\hline Gender & Male & 29 & 41 \\
\hline & Female & 41 & 59 \\
\hline & Total & 70 & 100 \\
\hline Type of school & Government school (girls) & 29 & 42 \\
\hline & Government school (boys) & 19 & 27 \\
\hline & Private school (girls) & 12 & 17 \\
\hline & Private school (boys) & 10 & 14 \\
\hline & Total & 70 & 100 \\
\hline
\end{tabular}

\section{Instrument}

Two sets of data (PIRLS test results and written narratives of the learners) were used for the study. The PIRLS test was obtained online and was used to determine the reading proficiency level of the grade 9 (form 2) learners, whereas the written narratives were used to provide an in-depth understanding of the learners' reading development, as well as their literacy abilities in general.

\section{Ethical clearance}

Ethical clearance was obtained from the ethics committee of the institution where the principal researcher was registered. Permission was also sought from the MOPSE and from the Ministry of Higher and Tertiary Education, Science, Innovation and Technology Development in Zimbabwe. After obtaining consent from the department of education and the principals of the schools, the learners were told about the study and requested to volunteer to participate. Consent was also sought from the learners' parents or guardians. Consent was also obtained from the teachers as well as the learners themselves on the day of the test and the collection of qualitative data.

\section{Data collection and procedure}

The principal researcher, together with the class teacher of each group of learners, administered the PIRLS test to the learners. The next day, the learners wrote the narratives during the English class period under the supervision of the principal researcher and the teacher.

\section{Data analysis}

The test results were analysed using ANOVA to determine the reading comprehension levels of the learners and the homogeneity of the two groups. The narratives were read by the principal researcher and a colleague. Content analysis was used to determine and isolate factors that influenced the learners' reading development using emergent and set themes such as parents' and teachers' influence, libraries, and socio-economic and affective issues. The overall language use and writing ability of the learners were also commented on.

\section{RESULTS AND DISCUSSION}

The learners' test results and findings from the narratives are presented to determine whether the crisis in Zimbabwe affected the cohort of learners' reading development. The government 
schools were represented by 48 learners, while private schools were represented by 22 learners.

\section{PIRLS test results}

For the sample of 70 learners from both government and private schools, within a range of $0 \%$ to $100 \%$, the mean score was $46.77 \%$ and the median score was $40 \%$. The overall mean score of $46.77 \%$ was below average. In other words, the learners could not obtain a $50 \%$ average in the test. The standard deviation of $34.47 \%$ and the coefficient of variation of $73.7 \%$ showed that there was a great deal of variability between the scores, as the coefficient of variation was far from zero. In other words, the learners' performance was spread across a wide range. While a number of students performed poorly, others recorded high marks.

Using the empirical rule, which provides a quick estimate of the spread of data in a normal distribution, about $68.26 \%$ of learners had an average ranging from $12.3 \%$ to $81.2 \%$ ( \pm one standard deviation from the mean). This shows a high inconsistency in the performance of the learners. This is shown in Figure 1, which presents the results of the comprehension test for all the learners in both private and government schools.

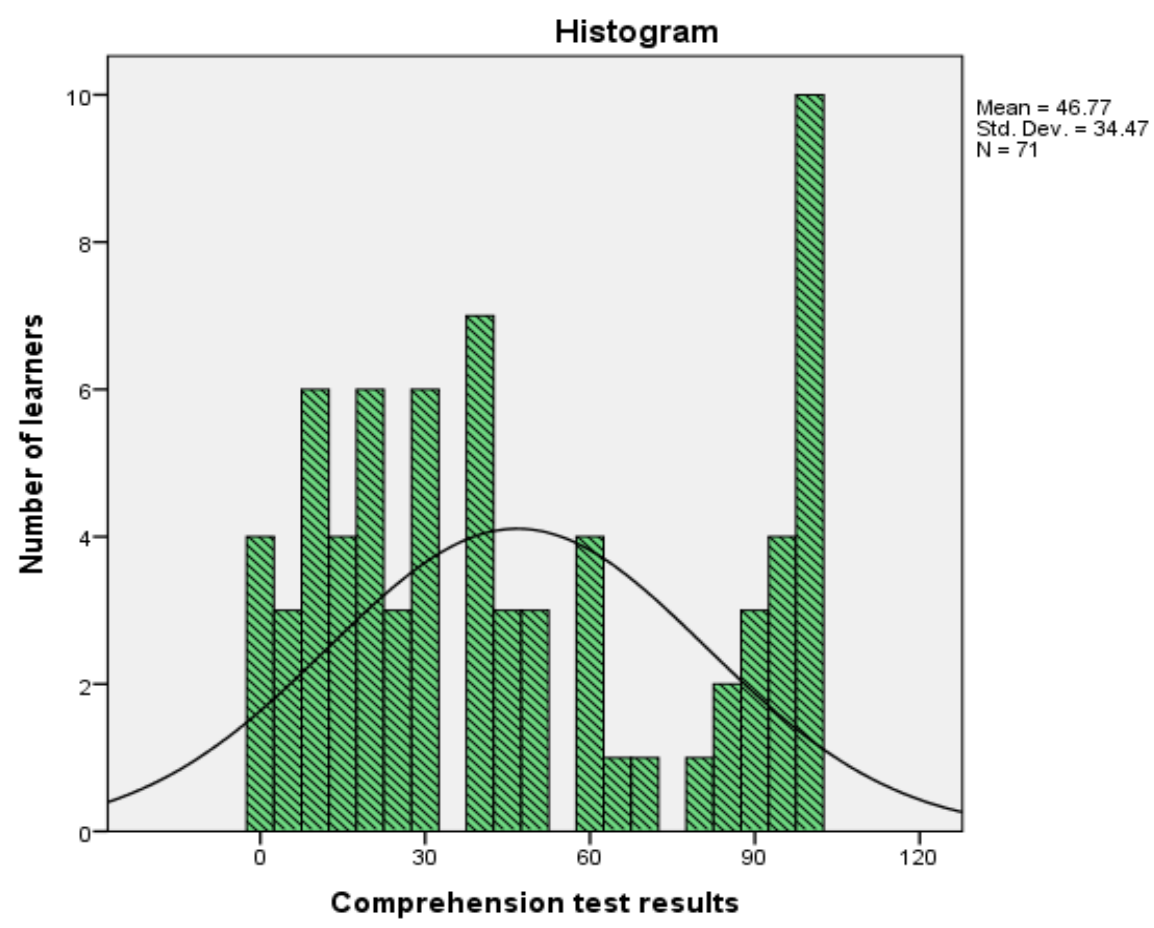

\section{Figure 1: Comprehension test results}

The histogram shows that the highest peak was at $100 \%$. Ten of the learners scored $100 \%$, while $14 \%$ of the learners got marks from $90 \%$ to $100 \%$. However, the majority $(63 \%)$ of the learners got marks below $50 \%$, indicating that the distribution was positively skewed; the mean was greater than the median.

A detailed analysis showed vast differences between the two schools. The average mean and standard deviation scores calculated showed that the private school learners obtained higher scores than the government school learners. The results are shown in Figure 2. 


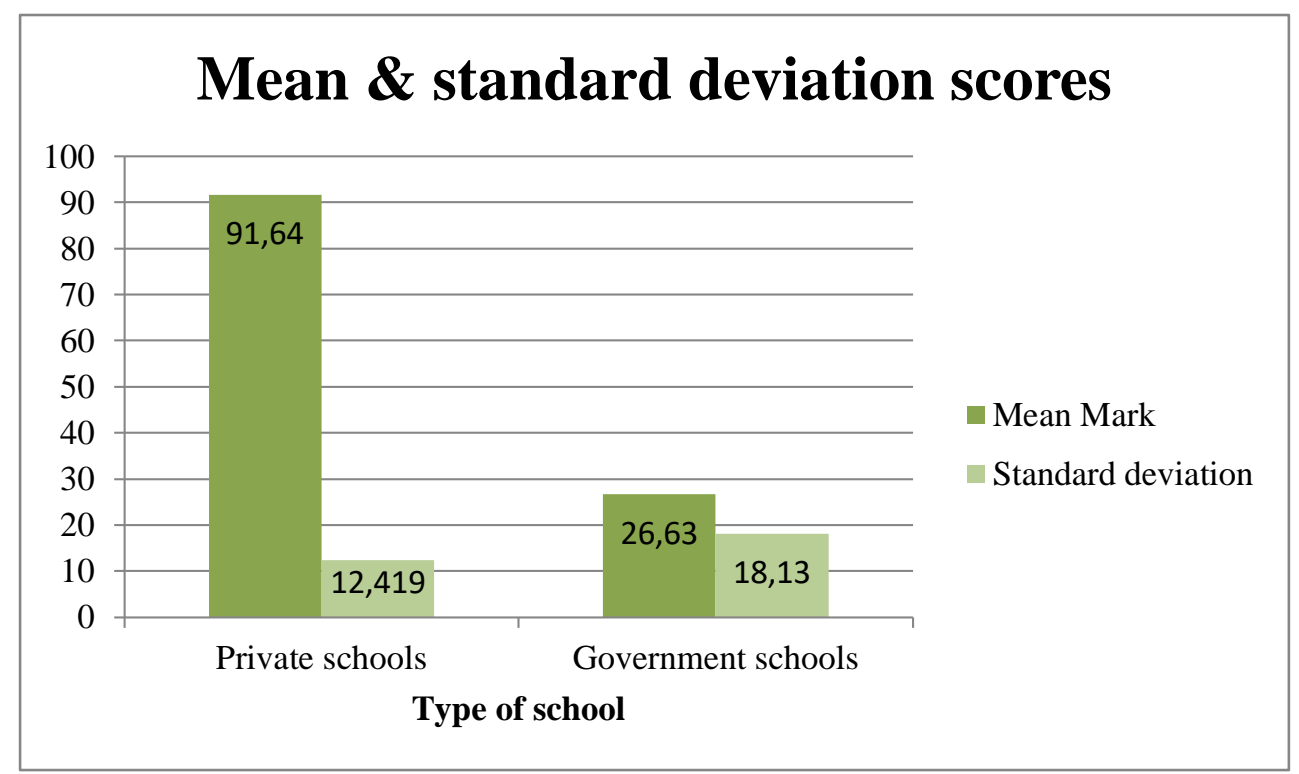

\section{Figure 2: Mean and standard deviation results by type of school}

The performance difference in the PIRLS (comprehension) test between private school learners and government school learners was statistically significant at a p-value of 0.001 The private school learners had an average of $91.64 \%$, compared to $26.63 \%$ for government school learners. The performance of government school learners was below average, and the standard deviation was wide, indicating that the scores were scattered away from the mean. The confidence interval error bars in Figure 3 show the non-overlap of performance by the learners from the two school types in the comprehension test.

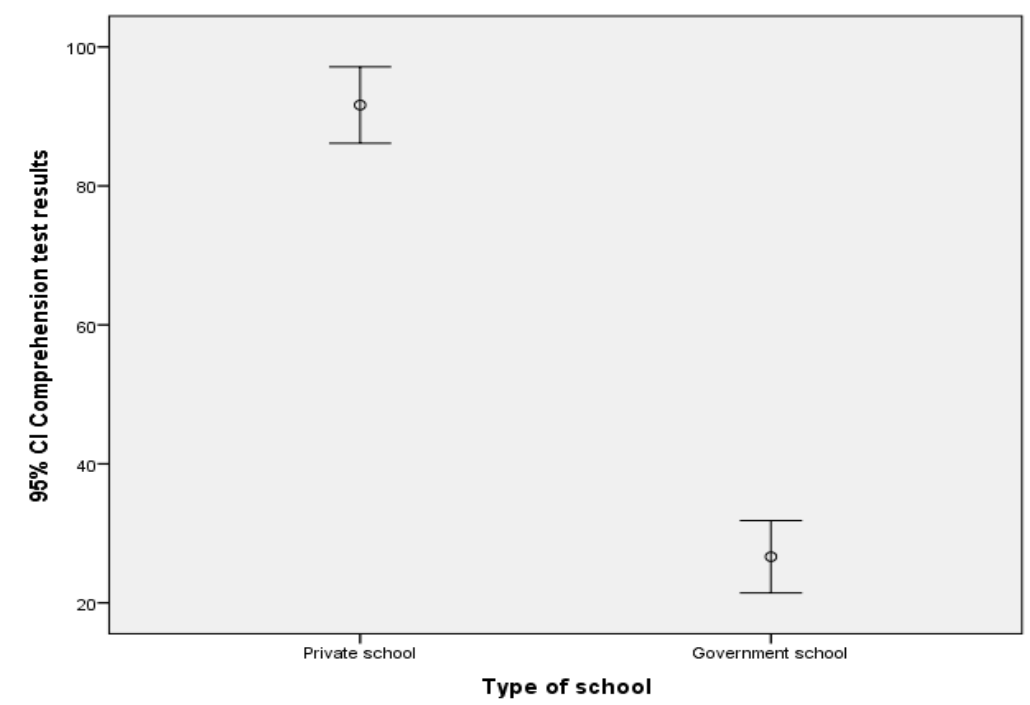

Figure 3: Error bars for performance in comprehension test by type of school attended

The error bars show the confidence interval to be between 80 and 100 for private school learners and between 20 and 30 for government school learners. The error bars further support the point that private school learners outperformed government school learners.

A plausible explanation for the better performance by the private school learners, among other factors, is the early reading instruction they received in their early years of tuition. As indicated by Crosby (2013), early reading instruction forms the foundation for strong literacy 
skills in the later years of schooling. In addition, there was stability in the private schools and learners were closely monitored with adequate pacing and classroom management by the teachers, as observed by Martins and Sass (2010). However, the government schools were experiencing challenges due to the economic crisis, and very little learning was taking place (Kanyeze et al. 2011). These students were denied the crucial early reading instruction that is vital for reading development in later years. As stated earlier, the government schools were experiencing disruptions, poor attendance at school, absenteeism by learners and teachers, as well as a lack of motivation among teachers and learners to engage in learning and teaching at school (Munangagwa, 2009). Although it seems obvious that learners in private schools would outperform learners in government schools, considering the limited resources that are usually available in government schools, the gap in the average test scores was extremely high: $91.64 \%$ (private school mean score) compared to $26.63 \%$ (government school mean score). Since the teachers in both schools had similar qualifications, the huge difference in the learners' performance could be attributed to the effect of the economic crisis on the government schools at the time.

The high achievement by private school learners may be attributed to the stability that prevailed at private schools, where there were adequate reading materials and adequate reading instruction for the development of the learners' comprehension and cognitive abilities. These learners also had high SES family backgrounds and were supported by parents and guardians, whereas the majority of the government school learners were from low SES homes, and to compound this, many parents had left the country to seek financial gains. SES has been argued to be strongly associated with many measures of childhood cognitive and academic achievement (Dexter, 2013); however, in the Zimbabwean context, and in the context of these two types of school, SES seems to have played an even more crucial role in the reading development of the learners.

The written narratives further confirmed the differences in the learners' reading comprehension levels and provided greater insights (Creswell, 2013) into their reading development, as well as the development of their English language proficiency in the early grades.

\section{Narratives}

The findings from the narratives further reveal that there were marked differences in the performance of the learners according to the school they attended. After analysing and coding by identifying common issues, as well as similarities and differences, the researchers drew together themes running through the narratives. Emergent and set themes in the learners' reading development included the role of mothers, teachers and the library. In addition, the overall use of language in the written narratives was analysed for grammatical errors to indicate the learners' language proficiency, which influences reading ability. Pseudonyms are used to identify the participants, and the excerpts from the narratives are quoted verbatim.

The findings from the narratives show family influence, specifically, that learners from both private and government schools were influenced by their mothers in terms of their literacy development. However, there were differences between the two types of school regarding the involvement. Whereas the majority of learners from the private schools mentioned the influence of their mothers, few learners in the government schools referred to their mothers' involvement. All the learners (100\%) from the private girls' high school (PGHS) and the majority of learners (90\%) from the private boys' high school (PBHS) acknowledged the 
involvement of their mothers. Less than half of the learners from both the government girls' high school (GGHS) (43\%) and the government boys' high school (GBHS) (31\%) attributed their literacy development to their mothers' involvement. Thus, the findings indicate that learners in private schools were generally supported by their mothers in their reading development, unlike those in government schools, where fewer learners had this support. Mwamwenda (2004) argues that mothers who have close relationships with their children play an important role in their language and literacy development. The premise that parents engaging their children in age-appropriate learning opportunities contributes positively to the children's reading development is supported by Bus (2001) and Gove and Cvelich (2011), and was confirmed in this study. Private school learners, most of whom were supported by their mothers, performed considerably better in the comprehension test than their government school counterparts. Mwamwenda (2004) confirms that the bond between mother and child enables mothers to teach their children the meanings of words before anyone else in the family, thus shaping and modifying their language and consequently their reading activities.

Due to the low SES families of the government school learners and the associated preponderance of low-income parents leaving home for greener pastures, the majority of the learners did not have the opportunity to experience reading interaction at home. The lack of home support may have resulted in a poor reading foundation, which may have contributed to their low reading proficiency, shown in the extremely low scores in the reading test.

Excerpts from the learners' narratives relating to the influence of their mothers on their reading development are provided to illustrate the differences between the language use of learners in the two schools.

Chelsey from the PGHS wrote: 'I remember my mother reading to me at a very young age. When I was a bit older, about grade one, she used to point out certain words to me. My mother told me that I was very determined to read, at a very young age.'

Thomas from the PBHS wrote: 'Every day after work hours my mom used to do reading exercises with me. I got better and better every session.'

Thandeka from the GGHS wrote: 'I started read and as star to read properly it was in grade 4. I will be continiue reading as my mother help me' [sic].

Bongani from the GBHS wrote: 'But my mother give me a short time to teach me reading until I was more adicted to readhing' [sic].

Excerpts from the learners' narratives also showed the teachers' influence on their reading journey. All learners (100\%) in the PGHS indicated that they had the support of teachers and $90 \%$ of PBHS learners indicated the same. Although $77 \%$ and $75 \%$ of GGHS and GBHS learners respectively mentioned the teachers' influence, they did not specifically explain the support. Perhaps the learners took the teachers' mere presence in the class to be support. Pamela from PGHS wrote: 'I am always grateful for the teachers who taught me how to read....' Watson from PBHS stated: 'Then I started grade one, where my teacher would make me practise reading.' Sibongile from GGHS wrote: 'The influence I get from my teachers in the classroom' [sic], while Temba from GBHS wrote: 'I started to be read at grade 5. The teacher that was N. Mphala...I am writing a composition learn to read. Because legs is seris. It's a long tym sins I go to last year. The November to go my reading journey. A tym when you were not reading' [sic]. The narratives written by learners from government 
schools lacked logic and there was no evidence from the narratives that teachers assisted them in reading. The predominance of the teachers' influence on reading development was observed in private school learners' narratives. Their sentence constructions and expressions were logical and precise. Narratives from the government school learners, on the other hand, displayed a restricted code, with sentences grammatically incorrect, direct and less conversational.

The library also featured in the learners' reading development. Although learners from both private and government schools mentioned the library as a resource in their reading development, very few learners from the government schools made this connection. All the private school learners indicated that they either went to the library during their spare time or were escorted to the library by their family members in order to do leisure reading.

Ninety-two percent of PGHS learners and 90\% of PBHS learners indicated the library's influence on their reading development. On the other hand, $61 \%$ of the GBHS learners and only $11 \%$ of the GGHS learners indicated the influence of the library. The library interactions of the private school learners meant that they read more often. Frequent reading contributes to reading proficiency (Grabe \& Stoller 2011) and may have influenced the learners' reading development in positive ways, as shown in their reading test results. In addition, the language proficiency of the private school learners was appropriate for their grade level, as reflected in their narratives and displayed in their correct grammar and spelling, as well as the higher quality of their sentence construction. The narratives of the private school learners showed appropriate language use, contrary to those written by government school learners, which reflected language use far below that expected for their grade level. The following examples indicate the learners' interactions with the library and also illustrate their language use.

Karen from the PGHS wrote: 'When my parents realised that I loved reading, they started paying for me to get books from the Public Library and since then reading has been my sacred haven.'

Gerald from the PBHS wrote: 'My mother would take me to the library once in a while but sometimes she would buy me books to read. At a later stage my mother bought me a kindle which I used for reading.'

Felistas from the GGHS wrote: 'They joint me library at town and at school. I donot go to the library to read. I normally phasteze answering qoustions' [sic].

Amkela from the GBHS wrote: 'Inforn I we go to library and talks books. Reading is a difficult thing. It the library read to match them everyone in ou class Anna saw that crocodile and whisperd his maller ayd for will happening in his son' [sic].

Although learners from all four schools indicated that the library had an impact on their reading development, the extent of the influence seemed to vary. The excerpts above testify to the fact that private school learners still demonstrated a sound level of language proficiency as compared to their government school counterparts. The premise that visiting a library is related to the reading development of learners further confirms Fasola's (2015) finding that learners who accessed the library regularly scored higher in their subjects than those who do not, as demonstrated by the performance of the learners from private schools. In addition, the premise that a well-furnished library with a variety of reading materials and qualified personnel helps learners improve their reading is also shown to be true by the 
narratives of the learners from private schools (Fasola, 2015). The private schools usually have well-resourced libraries. Furthermore, it has been observed that a library is the heart of the school and children build strong mental bases and academic ability due to reading (Todd, Gordon \& Lu, 2012). This has been the case for learners from the private schools. The private school learners further demonstrated liberty in using vocabulary they may have accumulated during their reading, while their government school counterparts seemed economical with their diction and at times regurgitated the comprehension passage that was given to them instead of focusing on their narratives.

For example, Phethokuhle from the GBHS wrote: 'I want to separate egg whit from yorh ...that bad hase Ara good story about Glamingos the crocadali amina saw that crocodile that crocodile broke the door and amina sturned' [sic].

The above excerpt was copied, though incorrectly, from the passage that was given to learners to read for the test.

Learners at the private schools not only used library materials, but their parents could afford to buy them electronic resources such as Kindles, as well as other reading materials. James (2014) indicates that a variety of reading is promoted in the library, not only through texts, but also through audio-visual and other related electronic resources. It is also evident that financial capital is a factor that can facilitate reading achievement, as it enables access to resources that parents provide for their children in order to keep their children reading outside school. Gerald from PBHS confirmed this when he wrote, 'My mother would take me to the library once in a while but sometimes she would buy me books to read. At a later stage my mother bought me a kindle which I used for reading.'

Furthermore, the excerpts from the learners' narratives underline the relationship between SES and reading achievement. Dexter (2013) states that there is a relationship between SES and a child's academic achievement. The excerpts from the private school learners indicate that the buying of reading materials such as books and electronic devices, such as the Kindle, enabled the learners from private schools to augment the library facilities and attain high reading achievement. The shortcomings of the learners from government schools in terms of spelling and sentence construction, as illustrated in the excerpts, could indicate a reading lag at grade 0 or grade $\mathrm{R}$ in 2008. As pointed out by Hindman and Morrison (2012: 347), reading gaps at kindergarten level are usually associated with a child's level of poverty, which is perceived as being caused by the lower SES of his or her parents.

Moreover, as Brown (2004: 26) states, 'reading is treated as one or more skills that also deal with listening, speaking and writing skills.' This premise was demonstrated by learners from the private schools as they displayed a good grasp of both spelling and vocabulary skills. The majority of the learners at private schools demonstrated a good command of the language and had started reading interactions from home and preschool, unlike their government school counterparts who had started reading interaction at a much later stage. For example, Karen from the PGHS wrote, 'This reading journey started as I entered the doors of my pre-school. I was young and innocent and didn't know what I was doing there...' '. In contrast, Temba from the GBHS wrote, 'I started to be read at grade 5. The techer that was N. Mphala. Which was a Good techerat the whole time...'. The learners from private schools scored highly in their reading comprehension test, exhibiting positive reading practices and strategies. The learners from government schools wrote flawed sentences trying to express their reading journey. The government school learners had not had reading foundations at 
home and at school, which seemed to have had an impact on their reading development. It is therefore not surprising that the learners' performance in comprehension tests was better in the private schools than in the government schools.

\section{CONCLUSION}

The findings have shed light on the reading proficiency of the cohort of learners. The quantitative data indicated that learners at the two types of school demonstrated different reading ability levels, as far as the reading comprehension level of grade 9 (form 2) learners in Bulawayo Central District high schools was concerned. The comprehension test results, through quantitative analysis, separated the two school types into error bars that showed a confidence interval from 80 to 100 for private school learners and from 20 to 30 for government school learners.

The comprehension test results are further supported by the findings from the qualitative data, where learners' narratives also revealed differences in the reading ability of learners at the two school types. The learners' language use in the narratives provided insight into their language proficiency, which reflected their reading proficiency, as language is one of the pillars for reading proficiency. It showed that learners from private schools demonstrated good reading prowess, while learners from government schools indicated a performance lag in reading. The learners from private schools demonstrated a high level of reading proficiency in their narratives by being able to use varied vocabulary, and appropriate and correctly constructed sentences, as well as displaying a good command of the language. In contrast, grammatical errors and spelling errors became exhibits of a lack of quality in the formative years of reading development for learners at government schools. Research also indicates that younger learners have more positive reading attitudes as they are considered more enthusiastic about beginning their reading journey than older readers (Knell, 2012). However, if the elementary years of reading do not ignite the reading interest, learners are at a disadvantage, as was the case with the learners at government schools in this study.

The following conclusion can be drawn from the findings: grade 9 (form 2) learners from government schools in the Bulawayo Central District of Zimbabwe are lagging behind in their reading proficiency. The implication of this is that, if these learners are not given special attention, including diagnostic instruction to overcome the reading comprehension lag, the reading comprehension gap will be carried over to secondary level and up to tertiary level. This could mean that the majority of the learners might either drop out or struggle to read, spending more years in education than are required. Another implication that could be gleaned from the findings is that economic instability plays a negative role in the education of learners, especially learners attending public schools. Non-governmental organisations and United Nations agencies confirmed that 2008 was a disastrous year in terms of learning and represented huge gaps in the education of Zimbabwe (UNICEF Zimbabwe, 2008). This study demonstrated that the reading proficiency of the government school learners who were in grade $\mathrm{R}$ in 2008 has shown evidence of these gaps.

The recommendation is for the Zimbabwean government to institute a high-level and sustainable intervention to redress the disadvantage of this cohort of Zimbabwean learners in government schools. First, the ministry of education, in liaison with the psychological services, could institute a mandatory assessment of learners at entry to grade 3 and grade 8 (form 1) in order to establish their reading proficiency level so that corrective measures are instituted. Secondly, the ministry could reintroduce the corrective reading programme, where 
learners with low reading proficiency are separated from the mainstream classes and provided with appropriate intervention tuition. The implementation strategy would also consider introducing a blueprint, that is, policy articulation, training of trainers, introducing in-service programmes for teachers and establishing a timetable for the programme at school level, and a teacher training syllabus that includes a component providing teachers with skills to handle learners with reading challenges. Finally, language teachers, particularly those teaching learners in grades 8 and 9 who have been disadvantaged, have to transform the traditional teaching of reading, which involves teaching reading comprehension for testing purposes. Instead, teachers should engage in reading instruction by cultivating in learners a reading culture where the learners make reading a habit that they enjoy and can undertake independently.

\section{REFERENCES}

ALLEN, LK, EL SNOW, SA CROSSLEY, GT JACKSON \& DS MCNAMARA. 2014. Reading comprehension components and their relation to writing. L'Année Psychologique, 114(4):663-691.

ANDERSON, C. 2000. Assessing reading. Cambridge: Cambridge University Press.

ANDERSON, R \& P PEARSON. 1984. A schema-theoretic view of basic processes in reading comprehension. Available from https://files.eric.ed.gov [Accessed: $12 \mathrm{March}$ 2020].

BESADA, H \& N MOYO. 2008. Zimbabwe in crisis: Mugabe's policies and failures. The centre for international governance innovation. Available from www.cigionline.org/workingpapers [Accessed: 2 May 2020].

BOAKYE, NAY. 2017. Efficacy of a reading intervention for first-year university students. Per Linguam, 33(1):1-24.

BOHLMANN, CA \& EJ PRETORIUS. 2002. Reading skills and mathematics: The practice of higher education. South African Journal of Higher Education, 16(3):196-206.

BROWN, HD. 2004. Language assessment: Principles and classroom practices. New York: Pearson Education.

BUS, A. 2001. Parent-child book reading through the lens of attachment theory. In L Verhoeven \& C Snow (Eds), Literacy and motivation: Reading engagement in individuals and groups. Mahwah: Erlbaum.

BYRAM, M. 2000. Routledge encyclopedia of language and learning. London: Routledge.

COLTART, D. 2008. A decade of suffering in Zimbabwe: Economic collapse and political repression under Robert Mugabe. CATO Institute, Washington D.C.

CRESWELL, JW. 2013. Qualitative inquiry \& research design: Choosing among five approaches (3rd ed.). Thousand Oaks: Sage.

CROSBY, RG. 2013. Reading attitudes as a predictor of Latino adolescents' reading comprehension. Doctoral thesis, University of California, Riverside. Available from http://www.escholarship.org [Accessed: 15 December 2019].

DENTON, C \& S OTAIBA. 2011. Teaching word identification to students with reading difficulties and disabilities. Focus on Exceptional Children, 43(7):1-16.

DEXTER, C. 2013. Family socioeconomic status and children's reading ability: The buffering effect of parental social support. Doctoral thesis, Wayne State University, Detroit. Available from https://digitalcommons.wayne.edu/oa_dissertations/759 [Accessed: 25 February 2020].

DHANAPALA, K \& J YAMADA. 2015. Reading processing skills among EFL learners in different proficiency levels. The Reading Matrix, 15(1):25-40. 
DUBE, S. 2015. Parents bay for the head's blood. Chronicle, 15 August.

EDMONDS, MS, S VAUGHN, J WEXLER, C REUTEBUCH, A CABLE, KK TACKETT \& JW SCHNAKENBERG. 2009. A synthesis of reading interventions and effects on reading comprehension outcomes for older struggling readers. Review of Educational Research, 79(1):262-300.

ENKIN, EB. 2014. Novel lexical item decoding in L2 reading acquisition: A socio-schematic approach. Unpublished master's dissertation, University of Massachusetts, Amherst. Available from https://scholarworks.umass.edu/cgi/viewcontent.cgi?referer=https://www.google.com/ $\&$ httpsredir $=1 \&$ article $=1218 \&$ context $=$ theses. . Accessed: 16 October 2017]

ERLINDA, DT \& LP ROINASOL. 2016. Reading comprehension vis-à-vis demographics, reading materials, \& time spent in reading. Journal of Arts and Humanities, 5(9):66-74. Available from http://theartsjournal.org/index.php/site/index [Accessed: 2 May 2020].

FASOLA, OS. 2015. Perceptions and acceptance of librarians towards using Facebook and Twitter to promote library services in Oyo State, Nigeria. The Electronic Library, 38(5):870-882. Available from http://www.emeraldinsight.com [Accessed: 3 November 2019].

GESKE, A \& A OZOLA. 2008. Factors influencing reading literacy at the primary school level. Problems of education in the $21^{\text {st }}$ century, 6(6):71-77.

GOUGH, PB \& WE TUNMER. 1986. Decoding, reading and reading disability: Remedial and special education. Available from http://psycnet.apa.org [Accessed: 22 April 2020].

GOVE, A \& P CVELICH. 2011. Early reading: Igniting education for all. A report by early learning community of practice (Revised ed.). Research Triangle Institute. Available from http://www.rti.org [Accessed: 15 March 2020].

GRABE, W \& FL STOLLER. 2011. Teaching and researching reading. London: Pearson. Available from http://www.usm.maine.edu [Accessed: 23 November 2019].

GRABE, W \& FL STOLLER. 2013. Teaching and researching reading. London: Taylor and Francis. https://doi.org/10.4324/9781315833743

GRANT, KB, SE GOLDEN \& NS WILSON. 2015.Literacy assessment \& instructional strategies: connecting to the common core. London: Sage.

GUMEDE, T. 2018. Factors influencing learners' reading ability in English in Bulawayo Central District high schools in Zimbabwe. Unpublished MA dissertation, University of Pretoria, Pretoria. Available from https://repository.up.ac.za/handle/2263/68023?show=full [Accessed: 4 May 2020]

GUTHRIE, JT. 2008. Reading motivation and engagement in middle and high school: Appraisal and intervention. In JT Guthrie (Ed.), Engaging adolescents in reading. Washington D.C.: Corwin Press, 1-16.

HARDING, L, JC ALDERSON \& T BRUNFAUT. 2015. Diagnostic assessment of reading and listening in a second language or foreign language. Elaborating on Diagnostic Principles, 32(3):317-336.

HINDMAN, AH \& FJ MORRISON. 2012. Differential contributions of three parenting dimensions to preschool literacy and social skills in a middle-income sample. MerrillPalmer Quarterly, 58(2):191-223.

HOFF, E. 2013. Interpreting the early language trajectories of children from low SES and language minority homes: Implication for closing achievement gaps. Developmental Psychology. 49(1):4-14. Available from http://www.researchgate.net/publication/22187672 [Accessed: 9 September 2019]. 
HUEY, EB. 1908. The psychology and pedagogy of reading. MA: MIT Press (1968). Special Edition (2009).

JAMES, PK. 2014. Enhancing reading through library and reference tools: RAN vacation reading programme. Library Philosophy and Practices. Available from: http://www.digitalcommons.unl.edu [Accessed 21 September 2019]

JIANG, X. 2017. Lower-level processing skills in English-as-a-second-language reading comprehension: Possible influence of first language orthography. Studies in English Language Teaching, 5(3):2329-3111. Available from www.scholink.org/ojs/index.php/selt [Accessed: 10 November 2019].

KANG, EY. 2015. Promoting L2 vocabulary learning through narrow reading. RELC Journal, 46(2). Available from http://www.journals.sagepub.com [Accessed: 15 November 2019].

KANYENZE, G, T KONDO, E CHITAMBARA \& J MARTENS (Eds). 2011. Beyond the enclave: Towards a pro-poor and inclusive development strategy for Zimbabwe. Harare: Weaver Press.

KNELL, E. 2012. The roles of motivation, affective attitudes and willingness to communicate among Chinese students in early English immersion programs. International Education, 41(2):5.

KUNG, FW. 2019. Teaching second language reading comprehension: The effects of classroom materials and reading strategy use. Innovation in Language Learning and Teaching, 13(1):93-104. https://doi.org/10. 1080/17501229.2017.1364252

LANDI, N. 2010. An examination of the relationship between reading comprehension, higher-level and lower-level reading sub-skills in adults. Reading \& Writing, 23(6):701-717. https://doi.org/10.1007/s11145-009-9180-z

LUKHELE, BBS. 2013. Exploring relationships between reading attitudes, reading ability \& academic performance among primary teacher trainees in Swaziland. Reading \& Writing, 4(1). https://doi.org/10.4102/rw.v4:1.28

MARTINS, NK \& D SASS. 2010. Construct validation of the behaviour \& instructional management scale. Teacher and Teacher Education, 26(5):1124-1135.

https://doi.org/10.1016/j.tate.2009.12.001

MILLENNIUM DEVELOPMENT GOALS. 2010. Status report Zimbabwe. Available from https://planipolis.iiep.unesco.org/en/2010/2010-millennium-development-goals-statusreport-zimbabwe-5171 [Accessed: 15 September 2015]

MINISTRY OF PRIMARY AND SECONDARY EDUCATION (MOPSE). 2012a. Early Reading Initiative Grade 1 \& 2. Teachers' manual. Harare: MOPSE.

MINISTRY OF PRIMARY AND SECONDARY EDUCATION (MOPSE). 2012b. The Performance Lag Address Programme. Teachers' manual. Harare: MOPSE.

MOYANA, R. 2000. Reading literacy at junior secondary level in Zimbabwe. Harare: University of Zimbabwe.

MUCHEMWA, S. 2014. Reading deficiencies among primary \& secondary school pupils: A case of Zimbabwe. US-China Education Review B, 4(3):193-201.

MUKOKO, M \& P MDLONGWA. 2014. A study to investigate the effectiveness of the Performance Lag Address Programme in improving students' performance in mathematics: A case study of students at Mutare Girls' High School in Zimbabwe. IOSR Journal of Research \& Method in Education, 4(4):42-55. Available from http://researchgate.net [Accessed: 20 April 2019].

MULLIS, IVS, MO MARTIN, P FOY \& KT DRUCKER. 2012. PIRLS 2011 international results in reading. Available from http://www.timssandpirls.bc.edu [Accessed: 8 June 2019]. 
MUNANGAGWA, CL. 2009. The economic decline of Zimbabwe. Gettysburg Economic Review, 3(9):1-22.

MUTEPFA, M, E MPOFU \& T CHATAIKA. 2007. Inclusive education in Zimbabwe: Policy, curriculum, practice, family and teacher education issues. Journal of the International Association for Childhood Education International Focus, 83(6):342-346.

MUZAWAZI, P \& E NKOMA. 2011. Working for higher achievement - closing the learning achievement gap. Teachers' manual. Zimbabwe government. Available from http://www.learning boorway.com/accelerated-learning principles.html [Accessed: 04 July 2019].

MWAMWENDA, TS. 2004. Educational psychology: An African perspective. South Africa: Heinemann.

NASSAJI, H. 2003. Higher-level and lower-level text processing skills in advanced ESL reading comprehension. The Modern Language Journal, 87:261-276. https://doi.org/10.1111/1540-4781.00189

NESS, MK. 2009. The use and attitudes towards reading comprehension instruction. Reading Horizons, 55(1):58-84.

NKOMA, E. 2014. Performance Lag Address Programme (PLAP): Teachers' perceptions and pedagogical approaches in Mutare urban P2 (former group B) primary schools. Journal of Business Management \& Social Sciences, 3(2):67-75.

NTEREKE, BB \& TB RAMOROKO. 2017. Reading competency of first-year undergraduate students at University of Botswana: A case study. Reading \& Writing, 8(11). https://doi.org/10.4102/rw.v8i1.123

OKEKE, C \& M VAN WYK. 2015. Educational research: An African approach. Cape Town: Oxford University Press.

ORGANISATION FOR ECONOMIC CO-OPERATION AND DEVELOPMENT (OECD) PISA. 2009. Assessment framework: Key competencies in reading, mathematics, and science. Available from http://www.oecd.org [Accessed: 10 May 2019].

PANIGRAHI, SS. 2010. Teaching of English. New Delhi: APH Publishing Corporation.

RICHARDSON, N. 2010. Guided reading strategies for reading comprehension education. Unpublished master's dissertation, St. John Fisher College, New York. Available from http://www.reflectivepractitioner.pbworks.com. [Accessed 15 March 2019].

ROBERT, JL. 2013. Effects of corrective reading as an intervention for Seventh Grade English Language learners. Doctoral dissertation, University of Southern Maine. Available from http://www.usm.maine.edu [Accessed: 23 October 2019].

SHARMA, D. 2007. Teaching English as a second language. New Delhi: Mayur Enterprises.

SIMMONS, DC, EJ KAME'ENUI, B HARN, DC MICHAEL, \& M STOOLMILLER. 2007. Attributes of effective \& efficient kindergarten reading intervention: An examination of instructional time \& design specificity. Journal of Learning Disabilities, 40(4):331347.

TAMRACKITKUN, K. 2010. Extensive reading: An empirical study of its effects on EFL Thai students' reading comprehension, reading fluency and attitudes. Unpublished doctoral thesis, University of Salford, Salford. Available from https://pdfs.semanticscholar.org/c139/461e77546fe0ad820c16fc0f037f0a1b40c2.pdf?.g $\underline{\mathrm{a}=2.201403857 .1567839030 .1588627121-2076554491.1587295417 .}$. [Accessed: 24 March 2019].

TAYLOR, S \& D YU. 2009. Socio-economic status and educational achievement: Does education provide a stepping stone out of poverty in South Africa? Transformation 
Audit,

66-75.

Available

from

http://www.ijr.org.za/publications/pdfs/IJR_TA_Prelims.pdf [Accessed: April 2020].

TODD, RJ, C GORDON \& Y-L LU. 2012. School libraries and development of intellectual agency: Evidence from New Jersey. Research Journal of the American Association of School Librarians, 15. Available from www.ala.org/aasl/slr [Accessed: 2 May 2020].

UNICEF-SNV, 2009. Final research report. Harare: UNICEF-SNV.

UNICEF ZIMBABWE. 2008. Immediate needs of children and women affected by the cholera outbreak of the health and education systems. Available from: http://unicef.org [Accessed: 7 October 2019].

VESAY, JP \& KL GISCHLAR. 2013. The big 5: Teacher knowledge and skill acquisition in early literacy. Reading Horizons: A Journal of Literacy and Language Arts, 52(3):281303.

WALCUTT, CC. 1967. Reading - a professional definition. The Elementary School Journal, 67:363-365.

\section{BIOGRAPHICAL NOTES}

Naomi A.Y. Boakye is a senior lecturer in the Unit for Academic Literacy at the University of Pretoria. Her research areas include academic literacy, academic reading, translanguaging, and English second language use. She teaches at honours and first-year levels and supervises Masters and Doctoral students. Naomi.boakye@up.ac.za

Thenjiwe Gumede is a lecturer at Hillside Teacers' College in Zimbabwe. Her research focuses on learners' reading comprehension. gthenjie@yahoo.co.uk 